\title{
Investigation of Chemical and Morphological Properties of the Sapwood and Heartwoods of Stone Pine and Black Locust
}

\author{
Saniye ERKAN* ${ }^{*}$, İbrahim BEKTAŞ @ \\ Kahramanmaraş Sütçü İmam University, Faculty of Forestry, Department of Forest Industrial \\ Engineering, Kahramanmaraş, TURKEY \\ *Corresponding Author: saniye.erkan@ hotmail.com
}

Received Date: 09.06.2020

Accepted Date: 25.06.2021

\begin{abstract}
Aim of study: The chemical and morphological properties of sapwood and heartwood of stone pine and black locust were determined.
\end{abstract}

Material and methods: Preparation of samples of stone pine and black locust sapwood and heartwood was carried out by adhering to the TAPPI Standard Methods. The chemical properties holocellulose, cellulose, lignin, alpha cellulose, ash, ether, cold and hot water and $1 \% \mathrm{NaOH}$ solubility percentages were analysed. In order to determine the morphological properties of the woods, the fiber size of the maserated wood samples were measured under a screened visopane microscope. Using the data obtained from fiber sizes, felting ratio, stiffness coefficient, runkel ratio, elasticity classification, Mühlstep coefficient and F factor values were calculated.

Main results: From the chemical analysis and morphological measurement results, significant differences were found according to the independent $\mathrm{T}$ Test statistical analysis between sapwoods and heartwoods. In addition, the solubility values of heartwoods were found to be lower than that of sapwoods, the chemical and morphological properties of all wood samples coincide with those specified in the literature.

Highlights: To investigate the suitability of Stone Pine and Black Locust to pulp and paper production.

Keywords: Sapwood and Heartwood, Stone Pine, Black Locust, Chemical and Morphological properties, Paper.

\section{Fıstıkçamı ve Yalancı Akasya Öz ve Diri Odunlarının Kimyasal ve Morfolojik Özelliklerinin Araştırılması}

\footnotetext{
Öz

Çalışmanın amacı: Fıstıkçamı ve yalancı akasya diri ve öz odunlarının kimyasal ve morfolojik özellikleri tespit etmek.

Materyal ve yöntem: Fıstıkçamı ile yalancı akasya diri ve öz odunu örneklerinin hazırlanması ve yapılan kimyasal analiz ve morfolojik ölçümler TAPPI standart yöntemine bağlı kalınarak gerçekleştirilmiştir. Çalışma kapsamında, kimyasal özelliklerinden holoselüloz, selüloz, lignin, alfa selüloz, kül oranı ile eter, soğuk su, sıcak su ile \%1'lik NaOH çözünürlüğü oranı analiz edildi. Odunların morfolojik özelliklerini belirlemek için, masere edilen odun örneklerinin lif boyutları ekranlı vizopan mikroskopta ölçülmüştür. Lif boyutları ölçümlerinden elde edilen veriler kullanılarak keçeleşme oranı, rijidite katsayısı, runkel oranı, elastikiyet sınıflandırması, mühlstep katsayısı ve $F$ faktörü değerleri hesaplanmıştır.

Temel sonuçlar: Kimyasal analiz ve morfolojik ölçüm sonuçlarından, fistıkçamı ile yalancı akasyanın diri ve öz odunları arasında yapılan bağımsız T Testi istatiktik analizine göre, önemli farklılıkların olduğu tespit edilmiştir. Ayrıca, diri odunlarının çözünürlük değerleri öz odunlara göre daha düşük bulunmuş ve tüm örneklerin kimyasal ve morfolojik özellikleri literatürdeki değerlerle örtüşmektedir.

Araştırma vurgulart: Fıstıkçamı ve Yalancı Akasya'nın kağıt hamuru ve kağıt üretimine uygunluğunu araştırmak.

Anahtar kelimeler: Diri ve Özodun, Fıstıkçamı, Yalancı Akasya, Kimyasal ve Morfolojik Özellikler, Kağıt.
} 


\section{Introduction}

When the cross section of the wood is examined, it is seen that it consists of three parts: pith, wood (heartwood, sapwood) and bark (xylem, phloem). In fact, the heartwood formed as a result of the aging of the sapwood is the woody part between the sapwood and the pith that can be affected by climate, soil and habitat conditions. The sapwood, on the other hand, is the woody part with living cells, usually light-colored, between the heartwood and shell parts. Its width affects from the tree stand, the age of the tree and the conditions of the growing place. When these two woody parts are compared; heartwood generally has harder, heavier, drier, lower hygroscopic and lower fiber saturation point than sapwood (Bozkurt \& Erdin, 1997; Bektaş et al., 2020). Bertaud \& Holmbom (2004) reported that heartwood has less cellulose and more lignin than sapwood and almost the same hemicellulose content. However, it was determined by Fengel and Wegener in 1989 (Fengel\& Wegener, 1989) that the extractive substance content of the heartwood is higher than the sapwood. By Ay \& Şahin (1998) and Mariana et al., (2005), in their studies on Picea orientalis and eucalyptus nitens wood, it was determined that the sapwood has larger fibers than the heartwood. Also, Mariana et al., (2005) and Liukkonen et al., (2007) reported that sapwood has a thicker fiber width. But, by Ay \& Şahin (1998) that the heartwood of the Picea orientalis has a thicker fiber wall thickness.

The chemical andanatomical differences between sapwood and heartwood often have a significant influence on pulping (Sjöström, 1981). Heartwood containing more extractive compared to sapwood increases the consumption of pulping chemicals and reduces the total pulp yield (Ataç \& Eroğlu, 2013; Gültekin, 2014; Erkan et al., 2020). Because of heartwood has lower permeability compared to sapwood, cooking liquor cannot penetrate into heartwood chips, and this increases the number of rejects (Pereira et al., 2003). By Esteves et al., (2005) in study, the dark colored maritime pine heartwood also decreases pulp brightness.
In the study, stone pine and black locust trees were used to determine the effect of sapwood and heartwood differences on chemical and morphological properties of wood. Separate analysis and measurements were performed for the sapwood and heartwood parts of the trees adhering to the standards. The differences between sapwood and heartwood were determined and their suitability for papermaking was investigated.

This study is the first study in the Turkey to determine the chemical and morphological properties of stone pine and black locust heartwood and sapwood. The results obtained are primarily scientifically important and will contribute to the literature in this field as well as contain data that can be used in the areas of use related to these two tree species.

\section{Material and Method Material}

In the tests, stone pine (Pinus pinea L.)tree obtain from, which is natural forest, Kozak plateau of Bergama of İzmir of Turkey, and black locust (Robinia pseudoacacia L.) tree taken from Ahır Mountain of Kahramanmaraş of Turkey, which is a planted forest. Some information about the trees used in the study is given in Table 1. Samples were obtained from the trees according to standard methods. For this purpose, three thick wedges with thickness of $5 \mathrm{~cm}$ were taken from $15 \mathrm{~cm}$ above the root level of each tree, right in the middle of the trunk and $15 \mathrm{~cm}$ below the crown. For chemical analyzes, the samples taken were divided parallel to the fibers. The samples taken to make the matchstick in size were broken. The sufficient amount of air-dried samples to be used in chemical analysis was ground in a laboratory type Wiley mill according to TAPPI T 257 om-85 standard method and sieved in shaking sieves of 40 mesh $(425 \mu)$ and 60 mesh $(250 \mu)$. The part that passed through the 40 mesh sieve and remained on the 60 mesh sieve was taken and put into glass jars with lids and prepared for use in chemical analysis. The moisture content of the prepared samples was determined by drying at $103 \pm 2^{\circ} \mathrm{C}$ in accordance with the TAPPI T 246 om- 88 standard. 


\section{Method}

The chemical properties of the test samples were determined by adhering to methods standard. Three replicates were performed for each analysis. The holocellulose and cellulose percentage were determined according to and Wise's chlorite methods and Kurschner-Hoffer nitric acid, respectively. The lignin, $\alpha$-cellulose, ashes were determined following standards TAPPI T 222 om-98, TAPPI T 203 om-93, TAPPI T 211 om-02, respectively. $\mathrm{NaOH} 1 \%$, ether and water solubilities were determined using TAPPI T 212 om-02, TS 4569(1985) and TAPPI T 207 om-93 respectively (Wise and Karl, 1962; Browning, 1967; Kurschner \& Hoffer, 1993). The morphological properties of test trees was determined by the maceration method and this method based on Wise's chlorite method was used to liberate the sample fibers prepared as matchstick size. Fiber dimension of wood fiber preparations prepared according to the TAPPI T $232 \mathrm{~cm}-85$ standard. Forty four measurements were made for each wood type. Fiber-length, fiber-width and lumen diameters of samples were calculated using screened viscose microscope (Bostanc1, 1987). Using the data obtained in the measurement; the felting ratio, rigidity (stifness) coefficient, runkel classification, elasticity coefficient, Mühlstep classification and $\mathrm{F}$ factor of fiber samples were calculated.

Table.1 Information on the trees used in the study

\begin{tabular}{llcccc}
\hline Tree type & Direction & $\begin{array}{c}\text { Altitude } \\
(\mathrm{m})\end{array}$ & $\begin{array}{c}\text { Trunk height of tree } \\
(\mathrm{m})\end{array}$ & $\begin{array}{c}\text { Trunk diameter of tree } \\
(\mathrm{cm})\end{array}$ & $\begin{array}{c}\text { Age } \\
(\text { year })\end{array}$ \\
\hline Stone pine & Southern & 550 & 6.10 & 35 & 31 \\
\hline Stone pine & Northern & 627 & 6.12 & 30 & 28 \\
\hline Stone pine & Eastern & 605 & 6.50 & 31 & 29 \\
\hline Stone pine & Western & 620 & 5.00 & 27 & 25 \\
\hline Black locust & Southern & 1600 & 6.75 & 20 & 21 \\
\hline
\end{tabular}

\section{Results and Discussion}

\section{Chemical Properties}

After preparing the heartwood and sapwood samples of Pinus pinea L. (Stone Pine) and Robinia pseudoacacia L. (Black Locust), moisture determination was made, the results were calculated as a percentage of the full dry sample weight. Table 2 shows the chemical analysis and solubility results in percent by weight.

Holocellulose is a polysaccharide consisting of the sum of cellulose and hemicellulose. In study, holocellulose determination of woody plant material was made according to acidified sodium chloride method developed by Wise and Karl in 1962. In this analysis, the residue left after removing lignin from woody material is called holocellulose. Hence, the term holocellulose refers to all polysaccharides in wood. Therefore, another name for holocellulose determination is delignification (Wise and Karl, 1962). From Table 2, it can be seen that there is $2-6 \%$ difference between the holocellulose amounts of sapwood and heartwood of the samples, the highest holocellulose percentation was measured in sapwood of black locust (80.7\%) and the lowest holocellulose percentage was measured in sapwood of stone pine $(72.2 \%)$. The percentation of holocellulose in coniferous and deciduous trees varies between $60-85 \%$ and in previous studies, the holocellulose percentage was obtained as $72.88 \%$ in sapwood of stone pine (Gönültaş, 2008 ), and $81.50 \%$ in black locust (Kırc1, 1987) and these results are consistent with the data obtained in the study. Holocellulose percentage of some coniferous and deciduous trees was found to be $70.80 \%$ in stone pine (Gümüşkaya et al., 2011), 65.40\% and $67.50 \%$, respectively in heartwood and sapwood of european black pine (Ataç \& Eroğlu, 2013), $70.11 \%$ and $73.60 \%$, respectively $81.9 \%$ and $80.9 \%$, respectively in sapwood and heartwood of Asian cypress poplar, $78.8 \%$ and $74.8 \%$, respectively in sapwood and heartwood of eucalyptus grandis (Gültekin, 2014). 
Table2.The result of chemical analysis of hearwood and sapwood of stone pine and black locust

\begin{tabular}{|c|c|c|c|c|c|c|c|c|c|c|c|}
\hline \multirow[b]{2}{*}{ 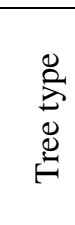 } & \multirow[b]{2}{*}{ 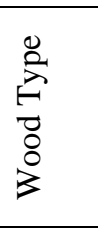 } & \multirow[b]{2}{*}{$\begin{array}{l}\frac{n}{n} \\
\frac{\pi}{\vec{a}} \\
\frac{\pi}{4}\end{array}$} & \multicolumn{9}{|c|}{ Chemical analysis and solubility results (\% - weigh) } \\
\hline & & & 응 $\frac{8}{3}$ & $\begin{array}{l}\frac{.}{o} \\
\frac{o}{\Xi} \\
\text { U }\end{array}$ & 㞼 & $\frac{0}{0}$ & 氞 & 矛獣 & 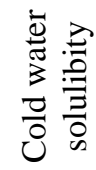 & 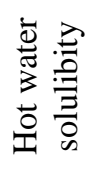 & 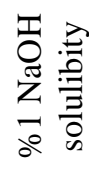 \\
\hline \multirow{8}{*}{$\begin{array}{l}0 \\
. \\
0 \\
0 \\
\tilde{0} \\
\dot{0}\end{array}$} & \multirow{4}{*}{ 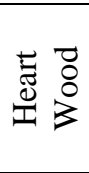 } & Mean & 75.7 & 45.8 & 28.8 & 62.5 & 0.18 & 24.66 & 10.02 & 13.54 & 37.8 \\
\hline & & S. Deviation & 1.19 & 0.52 & 0.07 & 0.01 & 0.1 & 0.47 & 0.52 & 0.52 & 1.04 \\
\hline & & Min. Value & 74.58 & 45.42 & 28.7 & 62.4 & 0.09 & 24.22 & 9.70 & 13.05 & 36.91 \\
\hline & & Max. Value & 76.97 & 46.4 & 28.8 & 62.5 & 0.29 & 25.15 & 10.61 & 14.08 & 38.95 \\
\hline & \multirow{4}{*}{ 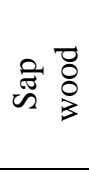 } & Mean & 72.2 & 48.7 & 27.5 & 65.4 & 0.36 & 6.15 & 9.74 & 11.25 & 32.45 \\
\hline & & S. Deviation & 0.01 & 1.14 & 0.18 & 0.54 & 0.03 & 0.18 & 0.06 & 1.85 & 0.17 \\
\hline & & Min. Value & 72.2 & 48.6 & 27.3 & 64.8 & 0.3 & 6.03 & 9.68 & 9.48 & 32.28 \\
\hline & & Max. Value & 72.3 & 48.9 & 27.6 & 65.9 & 0.4 & 6.36 & 9.80 & 13.18 & 32.62 \\
\hline \multirow{8}{*}{ 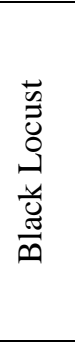 } & \multirow{4}{*}{ 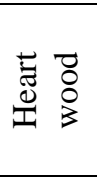 } & Mean & 78.4 & 50.5 & 24.6 & 60.5 & 0.21 & 11.57 & 10.67 & 11.56 & 22.68 \\
\hline & & S. Deviation & 1.07 & 0.74 & 0.08 & 0.53 & 0.06 & 0.28 & 0.20 & 0.46 & 0.39 \\
\hline & & Min. Value & 77.4 & 49.9 & 24.5 & 60.1 & 0.14 & 11.37 & 10.47 & 11.03 & 22.39 \\
\hline & & Max. Value & 79.6 & 51.3 & 24.6 & 61.1 & 0.24 & 11.89 & 10.87 & 11.85 & 23.12 \\
\hline & \multirow{4}{*}{ 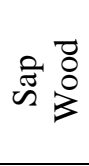 } & Mean & 80.7 & 49.3 & 23.9 & 63.3 & 0.41 & 9.25 & 10.13 & 10.36 & 20.3 \\
\hline & & S. Deviation & 0.97 & 0.12 & 0.20 & 0.18 & 0.06 & 0.07 & 0.30 & 0.27 & 0.16 \\
\hline & & Min. Value & 79.7 & 49.2 & 23.8 & 63.1 & 0.34 & 9.24 & 9.83 & 10.07 & 20.19 \\
\hline & & Max. Value & 81.7 & 49.5 & 24 & 63.4 & 0.44 & 9.26 & 10.43 & 10.54 & 20.48 \\
\hline
\end{tabular}

Wood, cotton, paper etc. lignocellulosic materials contain cellulose. It is the world's largest source of carbon and one of most polymers found in nature. It is indispensable for the pulp and paper industry. Cellulose analysiswas done according to KurschnerHoffner method. In this method, with the effect of nitric acid, fatty substances are dissolved, hemicelluloses are hydrolyzed and lignin turns into nitrophenolic compounds. However, cellulose is protected by the effect of alcohol (Browning, 1967). In this study, the highest cellulose value was calculated in heartwood black locust $(50.5 \%)$ and the lowest cellulose content was measured in heartwoodof stone pine $(45.8 \%)$. In terms of cellulose percentages, it can be seen from the data in Table 2 that the difference between sapwood and heartwood of black locust was low $(1.2 \%)$, whereas the difference between sapwood and heartwood of stone pine was greater $(2.9 \%)$. The percentage of cellulose in coniferous and deciduous trees is approximately $50 \%$. In studies by Kurc1 (1987) and by Gümüşkaya et al. (2011) the cellulose percentage was obtained as $52.70 \%$ (in black locust) and 51.14\% (in stone pine ).

This values are consistent with the values measured in this article. In some coniferous and deciduous trees, cellulose percentage was determined as $56 \%$ and $55.1 \%$, respectively in sapwood and heartwood of scotch pine, as $55.4 \%$ and 52.8\%, respectively in sapwood and heartwood of eucalyptus grandis (Gültekin, 2014), 53.35\% in Anatolian chestnut (Akgün, 2005).

Carbon source that is abundant in the earth after cellulose is lignin. It is, which one of the main componets of wood and annual plants, an organic substance (Pereira et al.,2003). Since it is non-fiber, hydrophobic and amorphous, it adversely affects the formation of hydrogen bonds between the fibers (Rydholm, 1965). Lignin percentage varies between $26-34 \%$ in coniferous wood and approximately $16-24 \%$ in coniferous wood (Browning, 1967). The lignin percentage obtained in the tests performed in this study was measured as the highest in heartwood of stone pine (28.8\%) and the lowest in sapwood of black locust (23.9\%). From these values, it is understood from the data in Table 2 that the difference among lignin percentages ofsapwood and heartwood of test trees $(1.3 \%$ in stone pine and $0.7 \%$ in black locust) is not highest. Lignin percentage of some trees was $29.56 \%$ for sapwood of Stone pine (Gönültaş, 2008), $25.78 \%$ for stone pine (Gümüşkaya et al., 2011), $25.3 \%$ and $26.9 \%$, respectively for 
sapwood and heartwood of european black pine (Ataç \& Eroğlu, 2013), 27.8\% and $26.6 \%$, respectively for sapwood and heartwood of uludag fir (Ataç \& Eroğlu, 2013), 20.9-25.8\%, respectively for heartwood of black locust (Dunisch et al., 2010), $22.9 \%$ and $21.1 \%$, respectively for sapwood and heartwood of eucalyptus grandis (Gültekin, 2014), 22.8\% and 21.8\%, respectively for sapwood and heartwood of Asian cypress poplar (Gültekin, 2014).

In alpha cellulose analysis, it is determined that the carbohydrates in the plant material are resistant to $17.5 \% \mathrm{NaOH}$ solution. Cross and Bevan divided the cellulose into three groups according to $17.5 \%$ solution. In the cold $17.5 \% \mathrm{NaOH}$ solution, the insoluble part was determined as alpha-cellulose, the part that was precipitated by neutralization of the soluble part was beta-cellulose and the part that was not precipitated by neutralization of the soluble part was determined as gammacellulose (Kırc1, 2006). Percentage of alpha cellolose in sapwood and heartwood of stone pine and black locust were measured as $62.5 \%, 65.45 \%, 60.5 \%$ and $63.3 \%$, respectively. In some studies on the subject, the percentage of alpha cellulose was $61.93 \%$ in stone pine sapwood (Gönültaş, 2008), $51 \%$ in black locust wood (K1rc1, 1987), 46.08\% in stone pine (Gümüşkaya et al., 2011), 69.7\%, 64.1\%, 70.5\%, 66.5\%, 71.6\%, $67.8 \%, 68.5 \%, 66.6 \%$ respectively in sapwood and heartwood of scotch pine, of red pine, of eucalyptus grandis and Asian cypress poplar (Gültekin, 2014), 44.6\%, $41.8 \%$ and $45.4 \%, 46.4 \%$, respectively in sapwood and heartwood of european black pine and uludağ fir (Ataç \& Eroğlu, 2013), $40.63 \%$ and $39.97 \%$ and $41.05 \%, 42.61 \%$, respectively in sapwood and heartwood of pedunculate oak and eastern beech (Ataç, 2009). In the alpha cellulose analysis conducted in this study, the calculated alpha cellulose percentage was determined according to the percentage of full dry holocellulose. However, in some of the studies in the literature, lower values were obtained than the percentage of alpha cellulose obtained in the study because the percentage ofthis analysis was calculated according to the extracted full dry wood. But,
Gönültaş (2008) reported the percentage of alpha cellulose analysis performed for stone pine wood supplied from three different regions of Turkey was calculated according to the ratio of full dry holocellulose and the results are listed; stone pine aplha celluose percentages are $63.13 \%$ and $61.60 \%$ for sapwood and heartwood of Çoruh region, $64.08 \%$ and $60.88 \%$ for sapwood and heartwood of Armutlu region and $61.93 \%$ for sapwood of Kozak region.

The amount of inorganic compounds in wood is determined by ash determination. As a result of burning of wood at $550-600^{\circ} \mathrm{C}$, it is determined by ash. In temperate zone trees, the proportion of inorganic matter varies between $0.1-1 \%$ compared to full dry wood, whereas in tropical and semi-tropical regions this rate increases up to 5\%. The ash content of the tree species growing in the temperate zone are mostly $\mathrm{Ca}, \mathrm{K}$ and $\mathrm{Mg}$ alkaline earth metals and a small amount of $\mathrm{Mn}, \mathrm{Na}$ and $\mathrm{P}$ compounds are also present. In the trees grown in tropical regions, $\mathrm{Si}$ is found in the composition of ash (Kircl, 2006). In our study, ash percentage of sapwood and heartwood of stone pine was $0.18 \%$ and $0.36 \%$, respectively and ash percentage of sapwood and heartwood of black locust was $0.21 \%$ to $0.41 \%$, respectively. Ash percentage of heartwoods is lower than sapwoods (around \%50) . In some studies, ash percentage is seen as $0.23 \%$ in sapwood of stone pine (Gönültaş, 2008), $0.54 \%$ in black locust (K1rc1, 1987) and is close to the data obtained in this study.

The amount of resins, oils, waxes, non volatile hydrocarbons, low molecular weight carbohydrates, salts, hydrolysed or nonhydrolyzed tannins, stilbenes, dyestuffs found in the wood is calculated by the ether solubility (TS 4569 (1985)). The extracts contained in the extraction slows down the delignification rate because of prevents bonding with water of the fibers during pulp production (Kırc1, 2006). Solubility of sapwood and heartwood of stone pine and black locust was found to be $24.66 \%, 6.15 \%$, $11.57 \%$ and $9.25 \%$, respectively. In the literature, stone pine sapwood alcohol solubility was seen as $0.15 \%$ (Gönültaş, 2008) and black locust alcohol solubility was seen as $6.70 \%$ (Kırc1, 1987), stone pine 
alcohol-benzene solubility was seen as 6.69\% (Gümüşkaya et al., 2011), anatolian chestnut alcohol solubility was seen as 19.87\% (Akgün, 2005), eurapean black pine sapwood and heartwood alcohol solubility was seen as $4.3 \%$ and $16.6 \%$, respectively (Eroğlu \& Ataç, 2013).

Cold water solubility was measured as $10.02 \%$ and $9.74 \%$, respectively for sapwood and heartwood of stone pine, and $10.67 \%$ and $10.13 \%$, respectively for sapwood and heartwood of black locust. The heartwoods from the samples of stone pine and black locust has a higher cold water solubility and there is not much difference $(0.28 \%$ in stone pine and $0.54 \%$ in black locust) in terms of the solubility values between the sapwood and heartwood. In other studies, cold water solubility was measured as $1.30 \%$ and $2.40 \%$, respectively in sapwood and heartwood of european black pine (Ataç \& Eroğlu, 2013), 2.89\% in stone pine (Gümüşkaya et al., 2011), $15.59 \%$ in Anatolian chestnut (Akgün, 2005). Inorganic substances, sugars, tannins, soluble polysaccharides, salts, dyes, organic acids, phenolic compounds and gums in woody plant material are determined by hot water extraction (Browning, 1967). The hot water solubility was obtained as $13.54 \%$ and $11.25 \%$, respectively for sapwood and heartwood of stone pine and $11.56 \%$ and $10.36 \%$, respectively for sapwood and heartwood of black locust. According to the obtained data, it is seen that the heartwood has a higher rate of hot water solubility than sapwood. In other studies, hot water solubility for stone pine sapwood was $3.62 \%$
(Gönültaş, 2008) and 8.10\% for black locust (Kırc1, 1987), $3.75 \%$ for stone pine (Gümüşkaya et al., 2011), $17.85 \%$ for anatolian chestnut (Akgün, 2005).

The $\mathrm{NaOH}$ solubility of $1 \%$ was calculated as $37.8 \%$ and $32.5 \%$ respectively, for heartwood and sapwood of stone pine, and $22.7 \%$ and $20.3 \%$, respectively for heartwood and sapwood of black locust. With this analysis, the percentage of broken cellulose, low molecular weight carbohydrates and polyoses found in the structure of woody plant materials is determined. It was determined that the heartwoods had higher solubility sapwoods. $\mathrm{NaOH}$ solubility analysis shows how much the yield of paper pulp will decrease (Browning, 1967). In previous studies, this solubility was determined as $15.57 \%$ for stone pine sapwood (Gönültaş, 2008), $22.10 \%$ for black locust (Kurc1, 1987), $15.64 \%$ for stone pine wood (Gümüşkaya et al., 2011), 32.90\% for anatolian chestnut (Akgün, 2005).

In the study, since the ratio of extractive material and ash in the samples subjected to holocellulose and lignin analysis was not determined, the total of holocellulose + lignin + extractive was calculated as higher than $100 \%$.

\section{Morphological Properties}

Table 3 and Table 4 shows the values of fiber dimensions of sapwood and heartwood of stone pine and black locust. Fiber micrographic measurement resuts gives in Table 5 and Table 6.

Table 3.The T-Test fiber size analysis results of Stone pine sapwood and heartwood ${ }^{(*)}$

\begin{tabular}{|c|c|c|c|c|c|c|c|}
\hline Fiber dimension & WT & Mean & SD & SE & $\begin{array}{c}\mathrm{COV} \\
(\%)\end{array}$ & $t_{\text {value }}$ & $\begin{array}{c}\text { Sig. } \\
\text { (2-tailed) }\end{array}$ \\
\hline \multirow{2}{*}{ Fiber length (mm) } & SW & 3.06 & 0.490 & 0.085 & 16.28 & \multirow{2}{*}{-7.215} & \multirow{2}{*}{0.000} \\
\hline & HW & 2.20 & 0.460 & 0.091 & 9.88 & & \\
\hline \multirow{2}{*}{ Fiber width $(\mu \mathrm{m})$} & SW & 50.64 & 2.193 & 0.403 & 4.52 & \multirow{2}{*}{14.22} & \multirow{2}{*}{0.000} \\
\hline & HW & 43.56 & 2.486 & 0.298 & 5.70 & & \\
\hline \multirow{2}{*}{ Lumen diameter $(\mu \mathrm{m})$} & SW & 31.01 & 3.143 & 0.509 & 10.13 & \multirow{2}{*}{22.11} & \multirow{2}{*}{0.000} \\
\hline & HW & 17.68 & 2.363 & 0.321 & 13.36 & & \\
\hline \multirow{2}{*}{ Double wall thickness $(\mu \mathrm{m})$} & SW & 19.45 & 0.617 & 0.100 & 3.17 & \multirow{2}{*}{25.20} & \multirow{2}{*}{0.000} \\
\hline & HW & 25.88 & 1.434 & 0.195 & 5.54 & & \\
\hline
\end{tabular}

${ }^{(*)}$ Number of samples: 44, WT: Wood type, SW: Sapwood, HW: Heartwood, SD: Standard deviation, SE: Standard error, COV: Coefficient of variation 
The fiber sizes of HW and SW of stone pine were given in Table 3 and the fiber sizes of the sapwood were statistically $(p<0.05)$ separated from their heartwoods. The basic cells in the fiber structure that make up the wood of coniferous trees are called traheids. According to the tree species, growing conditions and genetic variations, fiber length varies between $3-5 \mathrm{~mm}$ and fiber width varies between 30-50 $\mu \mathrm{m}$. Such fibers are called "long fibers" in papermaking and are very suitable for paper making (K1rc1, 2006). It is known that the increase in fiber length positively affects the resistance properties of the paper, but that too long fibers disrupt the formation of the paper. The thin-walled long fibers are easily crushed and the bond structure will be good during papermaking, the physical resistance properties of the paper will be high (Kirc1, 2000; Bektaş et al., 1999). When the fiber sizes of the stone pine tree are examined, it has been determined that the sapwood is longer fibrous and thicker wall than the heartwood. In some studies in the literature, for heartwood and sapwood of red pine, fiber length was calculated as $3.71 \mathrm{~mm}$ and $6.13 \mathrm{~mm}$, respectively fiber width was calculated as $65.91 \mu \mathrm{m}$ and $78.87 \mu \mathrm{m}$, respectively lumen diameter was calculated as $34.84 \mu \mathrm{m}$ and $36.78 \mu \mathrm{m}$, respectively (Gültekin, 2014). İstek et al. (2009) determined as $2.99 \mathrm{~mm}$ of fiber length, 47.48 $\mu \mathrm{m}$ of fiber width, $35.89 \mu \mathrm{m}$ of lumen diameter, $11.58 \mu \mathrm{m}$ of double wall thickness for beech pine.

Table 4. The T-Test fiber size analysis results of Black locust sapwood and heartwood ${ }^{(*)}$

\begin{tabular}{|c|c|c|c|c|c|c|c|}
\hline Fiber dimension & WT & Mean & SD & SE & $\begin{array}{c}\mathrm{COV} \\
(\%)\end{array}$ & $t_{\text {value }}$ & $\begin{array}{c}\text { Sig. } \\
\text { (2-tailed) }\end{array}$ \\
\hline \multirow{2}{*}{ Fiber length (mm) } & SW & 1.263 & 0.178 & 0.279 & 14.09 & \multirow{2}{*}{0.654} & \multirow{2}{*}{515} \\
\hline & $\mathrm{HW}$ & 1.29 & 0.201 & 0.318 & 15.58 & & \\
\hline \multirow{2}{*}{ Fiber width $(\mu \mathrm{m})$} & SW & 15.44 & 1.313 & 0.198 & 8.50 & \multirow{2}{*}{2.107} & \multirow{2}{*}{0.038} \\
\hline & HW & 14.88 & 1.208 & 0.182 & 8.11 & & \\
\hline \multirow{2}{*}{ Lumen diameter $(\mu \mathrm{m})$} & SW & 8.36 & 0.663 & 0.509 & 7.93 & \multirow{2}{*}{5.577} & \multirow{2}{*}{0.000} \\
\hline & HW & 9.40 & 1.055 & 0.321 & 11.22 & & \\
\hline \multirow{2}{*}{ Double wall thickness $(\mu \mathrm{m})$} & SW & 6.52 & 0.555 & 0.100 & 8.51 & \multirow{2}{*}{-5.039} & \multirow{2}{*}{0.000} \\
\hline & $\mathrm{HW}$ & 6.04 & 0.309 & 0.195 & 5.11 & & \\
\hline
\end{tabular}

${ }^{(*)}$ Number of samples: 44, WT: Wood type, SW: Sapwood, HW: Heartwood, SD: Standard deviation, SE:Standard error, COV: Coefficient of varition

The basic cells that make up the woods of the deciduous trees are called traces and the fiber length is between $0.8-1.5 \mathrm{~mm}$ and the fiber width is between $15-30 \mu \mathrm{m}$. Such fibers are when forming, very thick fibers also yield papers with low volume and resistance properties. The fiber wall thickness, on the other hand, effects the strength of the individual fibers (K1rc1, 2006). When the fiber size analysis result of the black locust tree are evaluated according to the data given in Table 4, it can be seen that there is a significant difference between sapwood and heartwood values at $p<0.05$ significance level. According to the data obtained in Table 4, black locust heartwood is longer fiber, thin-walled than sapwood. From heartwood and sapwood of pedunculate oak, fiber length was $0.974 \mathrm{~mm}$ and $1.240 \mathrm{~mm}$, respectively, fiber width was $18.40 \mu \mathrm{m}$ and $22.50 \mu \mathrm{m}$, respectively, lumen diameter was
$9.40 \mu \mathrm{m}$ and $9.80 \mu \mathrm{m}$, respectively and double wall thickness was $9.00 \mu \mathrm{m}$ and 12.70 $\mu \mathrm{m}$, respectively (Ataç, 2009). Fiber sizes of heartwood and sapwood of stone pine and black locust were analyzed and felting ratio, rigidity coefficient, runkel classification, elasticity coefficient, Mühlstep classification and $\mathrm{F}$ factor were calculated and the data obtained are given in Table 5 and Table 6.

Micrographic measurement result values values of the studies trees are evaluated with independent sample $\mathrm{T}$ test according to the data given in Table 5, it can be seen that there is a significant difference between sapwood and heartwood values at $p<0.05$ significance level. Felting ratio is calculated as the ratio of fiber length to fiber width. Although it is thought that fiber raw materials with a felting ratio below 70 are not valuable in terms of papermaking, It has been observed that the felting ratio does not show 
a systematic relationship with the physical properties of the paper, but only has a significant effect on the tear resistance of the paper (Bostanc1, 1987). It was found that felting ratio of heartwood was lower than sapwood (9.95). In the previous studies, the felting ratios of some coniferous trees was 82.63 of black pine, 61.80 of the beech pine (İstek et al., 2008;İstek et al., 2009), 66.56 and 71.76, respectively of heartwood and sapwood of uludağ fir (Ataç, 2009).

Table 5. The T-Test micrographic measurement results of Stone pine sapwood and heartwood ${ }^{(*)}$

\begin{tabular}{|c|c|c|c|c|c|c|c|}
\hline $\begin{array}{l}\text { Morphological } \\
\text { characteristic }\end{array}$ & WT & Mean & SD & $\mathrm{SE}$ & $\begin{array}{l}\mathrm{COV} \\
(\%)\end{array}$ & $t_{\text {value }}$ & $\begin{array}{c}\text { Sig. } \\
\text { (2-tailed) }\end{array}$ \\
\hline \multirow{2}{*}{$\begin{array}{l}\text { Felting } \\
\text { ratio } \\
\end{array}$} & SW & 60.36 & 1.170 & 0.214 & 1.93 & \multirow{2}{*}{-38.065} & \multirow{2}{*}{0.000} \\
\hline & HW & 50.41 & 0.820 & 0.090 & 1.62 & & \\
\hline \multirow{2}{*}{$\begin{array}{l}\text { Rigidity } \\
\text { coefficient }(\%)\end{array}$} & SW & 19.35 & 0.836 & 0.097 & 4.32 & \multirow{2}{*}{63.454} & \multirow{2}{*}{0.000} \\
\hline & HW & 29.66 & 0.715 & 0.135 & 2.41 & & \\
\hline \multirow{2}{*}{$\begin{array}{l}\text { Runkel } \\
\text { classification }\end{array}$} & SW & 0.63 & 3.143 & 0.066 & 10.13 & \multirow{2}{*}{34.720} & \multirow{2}{*}{0.000} \\
\hline & HW & 1.46 & 2.363 & 0.129 & 13.36 & & \\
\hline \multirow{2}{*}{$\begin{array}{l}\text { Elasticity } \\
\text { Coefficient }(\%)\end{array}$} & SW & 61.23 & 0.493 & 0.080 & 0.80 & \multirow{2}{*}{-184.660} & \multirow{2}{*}{0.000} \\
\hline & HW & 40.67 & 0.518 & 0.076 & 1.27 & & \\
\hline \multirow{2}{*}{$\begin{array}{l}\text { Mühlstep } \\
\text { classification (\%) }\end{array}$} & SW & 62.68 & 0.110 & 0.017 & 0.17 & \multirow{2}{*}{454.079} & \multirow{2}{*}{0.000} \\
\hline & HW & 83.52 & 0.260 & 0.036 & 0.31 & & \\
\hline \multirow[t]{2}{*}{$\mathrm{F}$ factor } & SW & 311.30 & 0.200 & 0.036 & 0.06 & \multirow{2}{*}{1998.424} & \multirow{2}{*}{0.000} \\
\hline & HW & 169.70 & 0.330 & 0.060 & 0.19 & & \\
\hline
\end{tabular}

${ }^{(*)}$ Number of samples: 44, WT: Wood type, SW: Sapwood, HW: Heartwood, SD: Standard deviation, SE: Standard error, COV: Coefficient of variation.

The stiffness coefficient expressed as 'fiber wall thickness x 100 / fiber diameter' relates to the thickness of the cell wall. For coniferous and deciduous trees, the rigidity coefficient is between 10-20. High rigidity coefficient value adversely affects paper breaking, tearing, bursting and double folding resistance (Bektaş et al., 1999). It was determined that the difference between sapwood and heartwood was high $(9.95 \%)$. In the literature, the rigidity (stiffness) coefficient of some trees was determined as $23.69 \%$ and $26.68 \%$, respectively in sapwood and heartwood of red pine (Gültekin, 2014), $17.14 \%$ in beech pine (İstek et al., 2009).

Runkel classification is calculated as the ratio of double wall thickness to lumen diameter. Fibers with runkel ratio greater than 1 are thick-walled, fibers with runkel ratio equal to 1 are medium thick-walled and fibers smaller than 1 are thin-walled. The dimensions of the fiber walls and the strength of the fiber are determined according to the Runkel classification. Papers obtained from very thin-walled fibers have low tear resistance. Since very thick-walled fibers do not flatten enough, they give low resistance properties and bulky papers (Kırc1, 2000).
Runkel classification in some studies was 0.89 and 1.14 , respectively for sapwood and heartwood of red pine (Gültekin, 2014) and 0.97 and 1.10 , respectively for sapwood and heartwood of scotch pine (Gültekin, 2014). The individual flexibility of the fibers and as well as the specific gravity of the wood from which the fibers are obtained are determined by calculating the elasticity coefficient. This coefficient is calculated by the formula '(lumen diameter x 100) / fiber width'. According to the formula, the fibers are classified into separate categories. Very flexible fibers with elastic coefficient greater than 75 (obtained from wood with a specific weight less than $0.5 \mathrm{~g} / \mathrm{cm}^{3}$ ), flexible fibers with elasticity coefficient between 75 and 50 (obtained from wood with a specific weight of $0.5-0.7 \mathrm{gr} / \mathrm{cm}^{3}$ ) rigid fibers with elastic coefficient between 30-50 (obtained from wood with a specific weight less than 0.7$0.8 \mathrm{~g} / \mathrm{cm}^{3}$ ) and very rigid fibers with elasticity coefficient greater than 30 (obtained from wood with a specific weight higher than $0.8 \mathrm{~g} / \mathrm{cm}^{3}$ (Kırc1, 2006). This coefficient is lower in heartwood of stone pine than sapwood and the difference is high $(20.56 \%)$. In the literature, the elasticity 
coefficient was $52.86 \%$ and $46.63 \%$, respectively for sapwood and heartwood of red pine (Gültekin, 2014), 74.78\% for beech pine (İstek et al., 2009).

Mühlstep classification provides preliminary information on how the morphological dimensions of the fibers affect the physical resistance properties of the paper. It is calculated by dividing the cell wall area of the fibers by the fiber crosssectional area. In the studies carried out in the literature, Mühlstep classification of some coniferous trees was $61.20 \%$ of red pine wood (Bektas et al., 1999), 57.49\% of black pine, $50.45 \%$ of beech pine (İstek et al., 2008; İstek et al., 2009). F factor is ratio of fiber length to fiber wall thickness and this value gives information about the flexibility of the papers to be obtained (Casey, 1961).

The $\mathrm{F}$ factor was calculated as 169.70 and 311.30, respectively in HW and SW of stone pine (as seen in Table 5). In some trees, The $\mathrm{F}$ factor was determined as 606.66 in the red pine (Bektaş et al., 1999), 586.38 as in the black pine and as 512.00 in beech pine (İstek et al., 2008; İstek et al., 2009).

Table 6. T Test micrographic measurement results of Black locust sapwood and heartwood ${ }^{(*)}$

\begin{tabular}{|c|c|c|c|c|c|c|c|}
\hline $\begin{array}{l}\text { Fiber } \\
\text { micrographic }\end{array}$ & WT & Mean & SD & SE & $\begin{array}{c}\mathrm{COV} \\
(\%)\end{array}$ & $t_{\text {value }}$ & $\begin{array}{c}\text { Sig. } \\
\text { (2-tailed) }\end{array}$ \\
\hline \multirow{2}{*}{$\begin{array}{l}\text { Felting } \\
\text { ratio }\end{array}$} & SW & 84.87 & 0.620 & 0.100 & 0.73 & \multirow{2}{*}{-6.747} & \multirow{2}{*}{0.000} \\
\hline & HW & 83.74 & 0.820 & 0.130 & 0.97 & & \\
\hline \multirow{2}{*}{$\begin{array}{l}\text { Rigidity } \\
\text { coefficient }(\%)\end{array}$} & SW & 21.50 & 0.420 & 0.060 & 1.95 & \multirow{2}{*}{-24.845} & \multirow{2}{*}{0.000} \\
\hline & HW & 19.48 & 0.380 & 0.050 & 1.95 & & \\
\hline \multirow{2}{*}{$\begin{array}{l}\text { Runkel } \\
\text { classification }\end{array}$} & SW & 0.77 & 0.030 & 0.004 & 3.89 & \multirow{2}{*}{-20.499} & \multirow{2}{*}{0.000} \\
\hline & HW & 0.64 & 0.020 & 0.004 & 3.16 & & \\
\hline \multirow{2}{*}{$\begin{array}{l}\text { Elasticity } \\
\text { coefficient }(\%)\end{array}$} & SW & 56.39 & 0.330 & 0.053 & 0.58 & \multirow{2}{*}{66.738} & \multirow{2}{*}{0.000} \\
\hline & HW & 60.94 & 0.300 & 0.042 & 0.49 & & \\
\hline \multirow{2}{*}{$\begin{array}{l}\text { Mühlstep } \\
\text { classification }(\%)\end{array}$} & SW & 68.43 & 0.070 & 0.012 & 0.10 & \multirow[t]{2}{*}{-301.405} & \multirow[t]{2}{*}{0.000} \\
\hline & HW & 62.93 & 0.090 & 0.013 & 0.14 & & \\
\hline \multirow[t]{2}{*}{ F factor } & SW & 387.43 & 0.111 & 0.020 & 0.02 & \multirow[t]{2}{*}{1798.794} & \multirow[t]{2}{*}{0.000} \\
\hline & HW & 428.14 & 0.055 & 0.010 & 0.01 & & \\
\hline
\end{tabular}

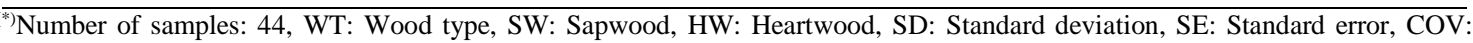
Coefficient of variation

As seen in Table 6, The felting ratio, rigidity coefficient $(\%)$, runkel classification, elasticity coefficient (\%), Mühlstep coefficient (\%) and F Factor were calculated for HW and SW of black locust. As can be understood from T-test analysis results, micrographic measurement results of sapwood and heartwood significantly $(p<0.05)$ differed from each other. In the previous studies, the felting ratio of some deciduous trees was found as 49.53 in white willow, 45.96 in black poplar (Alkan et al., 2003). When this ratio was higher than 70; It is reported that tear, rupture and double folding resistances of the paper will be high (Bektaş et al., 1999; Kırc1, 2006). In the felting ratio expressed as fiber length / fiber width, the increase in fiber length positively affects the ratio. Therefore, it will be better to felting ratio of the papers to be obtained from long fiber raw materials. However, too long fibers create flocculation on the surface in paper making and disrupt the formation of the paper (Bostanc1, 1987).

The rigidity coefficient is directly related to the cell wall thickness. The size of the number obtained as a result of the proportion reduces the physical resistance properties of the paper (Tank, 1980). As given in Table 6, it is seen that the difference between sapwood and heartwood of black locust is less $(2.02 \%)$. In some studies, was found as $28.21 \%$ and $25.31 \%$ respectively, in sapwood and heartwood of eucalyptus grandis (Gültekin, 2014). Likewise, as can be seen from Table 6, runkel classification of HW and SW of black locust was 0.64 and 0.77 , respectively. Runkel classification was 1.02 and 1.28 , respectively for sapwood and heartwoodof eucalyptus grandis (Gültekin, 2014). The fibers with a runkel ratio less than 1 belong to the class of thin-walled fibers and are most suitable for papermaking. In 
papermaking, this ratio is desired to be equal to 1 and less than 1 (Kırc1, 2000).

Demonstrated in Table 6, black locust heartwood has a higher coefficient of elasticity than sapwood (4.55\%). In similar studies, this coefficient was $54 \%$ of eucalyptus camaldulensis (El Moussaouiti et al., 2012), $60.21 \%$ of populous tremula (Özkan, 2006), 43.76\% and 49.37\%, respectively of eucalyptus grandis (Gültekin, 2014). Fibers with a coefficient greater than 75 are very flexible fibers. Although their fibers are suitable for pulp and papermaking, they have very fine fibers and their tear resistance will be low. In the values between 50-75 flexible fibers, partially crushed during papermaking and high quality paper will be obtained (Bostanc1, 1987; Bektaş et al., 1999).

As the positively affects the flexibility of paper, it is requested that the Mühlstep classification is determines the effect of the fiber wall on the physical properties of the paper. Thin-wall fibers are easily crushed in papermaking and positively affect the density and resistance properties of the paper (K1rc1, 2000). As seen in Table 6, Mühlstep classification of HW and SW of black locust was calculated as $62.93 \%$ and $68.43 \%$, respectively. By Alkan et al. (2003), this classification was found as $55.37 \%$ in white willow wood, $57.56 \%$ in black poplar.

As can be given from Table 6, in HW and SW of black locust, F factor was found to be 428.14 and 387.42 , respectively. In the literature, for some deciduous trees, the $\mathrm{F}$ factor was noted as 298.45 in white willow wood, 250.75 in black poplar wood, 165.82 in the eastern plane-tree, 198.33 in common ash wood (Alkan et al., 2003).

The effect of tracheal and tracheal on the physical resistance properties of paper is great. In Table 7, the relationships between the morphological properties of the fibrous cells and the physical properties of the paper are given. It can be seen from the Table 7 that all physical resistance properties (bursting, tearing and double-folding) except the density of the paper improved with increasing fiber length and the strength of the paper increased. Generally, if the fiber length increases, the bursting, tearing and doublefolding resistance of the paper increases. As the fiber wall thickness increases, bursting and double-folding resistance increases and tear resistance and density of paper decrease (Dadswell \& Watson, 1961; from Bostanc1, 1987).

Table 7. Relationship between fiber morphological properties and physical properties of paper (Dadswell \& Watson, 1961; from Bostanc1, 1987)

\begin{tabular}{|c|c|c|c|c|}
\hline Relationships & $\begin{array}{l}\text { Explosion } \\
\text { resistance }\end{array}$ & $\begin{array}{l}\text { Tear } \\
\text { resistance }\end{array}$ & $\begin{array}{l}\text { Double Folding } \\
\text { resistance }\end{array}$ & $\begin{array}{l}\text { Density of } \\
\text { paper }^{(*)}\end{array}$ \\
\hline As fiber length increases & + & ++ & + & - \\
\hline As cell wall thickness increases & - & + & -- & -- \\
\hline As cell wall thickness decreases & + & - & ++ & ++ \\
\hline Fiber length / Fiber width increases & & & + & \\
\hline Fiber curl increases & -- & + & + & - \\
\hline
\end{tabular}

\section{Conclusions}

The results obtained in the study examining the chemical and morphological properties of heartwood and sapwood of stone pine and black locust trees are listed below;

-When the chemical properties are examined: It was determined that heartwoods have higher lignin $(4.72 \%-2.92 \%)$, ether solubility $(300.97 \%-25.08 \%)$, hot water solubility $(20.35 \%-11.58 \%)$, cold water solubility $(2.87 \%-5.33 \%), 1 \% \quad \mathrm{NaOH}$ solubility $(16.48 \%-11.72 \%)$ and lower alpha cellulose $(4.64 \%$ - 4.62\%), ash percentage $(100 \%$ - 95.23\%) compared to sapwood. However, the highest values for the percentage of cellulose and holocellulose were obtained from the heartwood of black locust $(50.5 \%)$ and in the sapwood of black locust $(80.7 \%)$.

-Again, stone pine sapwood is longer fiber $(39.09 \%)$, thinner-walled $(33.05 \%)$ and 
wider lumen $(75.39 \%)$ than heartwood. But, it was determined that the sapwood of black locust is shorter fiber (2.13\%), thicker walled (7.94\%) and narrower lumen (12.44\%) than heartwood. On the other hand, according to the micrographic measurement results, it was understood that there were significant differences between the sapwood and heartwood of stone pine (131.74 in runkel classification, 83.44 in $\mathrm{F}$ factor, $53.28 \%$ in rigidity coefficient, $50.55 \%$ in elasticity coefficient, $33.24 \%$ in mühlstep classification, 19.73 in felting ratio).

- Also, according to the $\mathrm{T}$ test analysis, statistically significant differences were found between the heartwoods and sapwoods of the experimental trees at $95 \%$ confidence level.

As is known, the differences between the chemical and morphological properties of heartwood and sapwood have an important effect on the properties of pulp and paper. In this respect, in a pulp mill, it may not be economical to uncombine the heartwood and sapwood of the tree before pulping. However, knowing these differences can contribute to better control of the processes taking place during pulp preparation and papermaking and more accurate estimation of final product properties.

Based on the findings obtained within the scope of the study, it can be suggested that stone pine is suitable for kraft (sulphate) and soda methods among chemical pulp production methods, similarly, the black locust due to its short fiber, narrow lumen and thin-walled texture is suitable for pulp production with soda method.

\section{Ethics Committee Approval N/A}

\section{Peer-review}

Externally peer-reviewed.

\section{Author Contributions}

Conceptualization: $\quad$ S.E., İ.B.; Investigation: S.E.; Material and Methodology: S.E., İ.B.; Supervision: İ.B. Visualization: S.E.; Writing-Original Draft: S.E.; Writing-review\&Editing: S.E. All authors have read and agreed to the published version of manuscript.

\section{Conflict of Interest}

The authors have no conflicts of interest to declare.

\section{Funding}

This study has been supported within the scope of project numbered $2011 / 7-14$ YLS by Kahramanmaras Sutcu Imam University, Scientific Research Projects Coordination Department.

\section{References}

Akgün, H.C. (2005). Chemical composition of Anatolian chestnut wood and suitability for pulping. M. Sc. Thesis, Graduate School of Natural and Applied Sciences, Department of Forest Industrial Engineering, Zonguldak Karaelmas University, Bartın, Turkey.

Alkan, Ç., Eroğlu, H. \& Yaman, B. (2003). Fiber morphology of some natural Angiospermae taxa in Turkey, Zonguldak Karaelmas University, Bartın the Faculty of Forestry Journal, 5(5), 102-108.

Ataç, Y. (2009). Examination of softwood and hardwood trees in terms of paper properties of their sapwood and heartwood. Ph. D. Thesis, Graduate School of Natural and Applied Sciences, Department of Forest Industrial Engineering, Bartın University, Bartın, Turkey.

Ataç, Y. \& Eroğlu, H. (2013). The effects of heartwood and sapwood on kraft pulp properties of Pinus nigra J.F. Arnold and Abies bornmuelleriana Mattf. Turkish Journal of Agriculture and Forestry, 37, 243-248.

Ay, N. \& Şahin, H. (1998). An investigation of internal morphological properties of sapwood and heartwood of oriental spruce (Picea orientalis Link.). Turk J. Agric. For, 22, 203207.

Bektaş, İ.,Tutuş, A. \& Eroğlu, H. (1999). A study of the of Calabrian pine (Pinus brutia Ten.) for pulp and paper manufacture. Turkish journal of Agriculture and Forestry, 23, 589598.

Bektaş, İ., Tutuş, A. \& Gültekin, G. (2020). The Effect of Sapwood and Heartwood Differences on Mechanical Properties of FastGrowing Tree Species. Drvna industrija: Znanstveni časopis za pitanja drvne tehnologije, 71(3), 261-269.

Bertaud, F. \& Holmbom, B. (2004). Chemical composition of earlywood and latewoods in Norway Spruce heartwood, sapwood and transition wood. Wood Science Technology, $38,245-256$. 
Bostanc1, Ş. (1987). Pulp Production and Bleaching Technology. University Publication No.114, Faculty Publication No.13. Trabzon: Karadeniz Technical University Printing House.

Bozkurt, Y. \& Erdin, N. (1997). Wood Technology. İstanbul University, Publications of Faculty of Forestry, no. 445, İstanbul.

Browning, B.L. (1967). Methods of Chemistry. I, New York, London, Sydney: Interscience Publishers.

Casey, J.P. (1961). Cellulose and Paper Chemistry and Chemistry Technology. III. Edition, (2), 581-1249. New York: WileyInterscience Publishers Inc.

Dadswell, H.E. \& Watson, A.J. (1961). Influence of the Morphology of Wood Pulp Fibers on Paper Properties, In: Bloam, F., ed. Formation and Structure of Paper. (2), 537-564. London, England: Technical Section of the British Paper and Board Markers Association.

Dunisch, O., Richter, H. G. \& Koch, G. (2010). Wood properties of juvenile and mature heartwood in R. Pseudoacacia L. Wood Science and Technology, 44(2), 301-313.

El Moussaouiti, M., Barcha, B., Alves, E.F. \& Francis, R.C. (2012). Kraft Pulping of Eucalypti, Bioresources, 7 (2), 1558-1568.

Erkan, S., Çiçekler, M. \& Tutuş, A. (2020). Comparison of Pinus Pinea Heartwood and Sapwood Pulps Obtained by Soda-Potassium Borohydride Method. Düzce University, Journal of Science and Technology, 8(3), 1894-1902.

Esteves, B., Gominho, J., Rodrigues, JC., Miranda, I. \& Pereira, H. (2005). Pulping yield and delignification kinetics of heartwood and sapwood of maritime pine. J Wood Chem Technol, 25, 217-230.

Fengel, D. \& Wegener, G. (1989). Wood: Chemistry, ultrastructure, reactions. Walter de Gruyter, New York.

Gönültaş, O. (2008). Chemical characterization of cones, wood and needles of Pinus pinea. Msc. Thesis, İstanbul University, Institute of Science, İstanbul, Turkey.

Gültekin, G. (2014). Determination of Chemical, Morphological, Anatomical, Physical and Mechanical Properties of Sapwood and Heartood of Some Softwood and Hardwood. Ph. D. Thesis, Institute of Science and Technology, Department of Forest Industry Engineering, Kahramanmaras Sutcu Imam University, Kahramanmaraş, Turkey.

Gümüşkaya, E., Erisir, E., Kırcı, H. \& Misir, N. (2011). The Effect of Sodium Borohydride on Alkaline Sulfite Anthraquinone Pulping of Pine (Pinus pinea) Wood. Industrial $\delta$
Engineering Chemistry Research, 50, 83408343.

İstek, A., Eroğlu, H. \& Gürsoy, S.K. (2008). Fiber and Paper Properties Changes in Relation to age of Black Pine. Kastamonu University Journal of Forestry Faculty, 8(1), 61-66.

İstek, A.,Tutuş, A. \& Gülsoy, S.K. (2009). The Effect of Tree Age on Fiber Morphology of Pinus pinaster and Paper Properties. KSU Journal of Engineering Sciences, 12(1), 1-5.

Kirc1, H. (1987). Possibilities of evaluation of Robinia pseudoacacia L. wood in paper industry", Master Thesis, Institute of Science and Technology, KTU, Trabzon, Turkey.

Kirc1, H. (2000). Pulp Industry Lecture Notes. Pub. No:63, KTU, Faculty of Forestry, Trabzon.

Kırc1, H. (2006). Pulp Industry Lecture Notes. Publication No. 86,113. Trabzon: KTU, Faculty of Forestry.

Kurschner, K. \& Hoffer, A. (1993). Cellulose and cellulose derivative, Fresenius, Journal of Analytical Chemistry. 92(3), 145-154.

Liukkonen, S., Vehnianinen, A. \& Sirvio, J. (2007). Selection of raw material offers new energy-property combinations for mechanical pulp. International Mechanical Pulping Conference, Minnesota, USA, 1-9.

Mariana, S., Torres, M., Fernandez, A. \& Morales, E. (2005). Effects of Eucalyptus nitens heartwood in kraft pulping. Tappi $\mathbf{J} 4$, 8-10.

Özkan, İ. (2006). Production of $\mathrm{NaBH}_{4}$ Addition Kraft Paper Pulp from Populus Tremula L. P Chips. High Engineering Thesis. Zonguldak Karaelmas University Institute of Science. Bartın, Turkey.

Pereira, H., Graça, J. \& Rodrigues, J.C. (2003). Wood chemistry in relation to quality. In: Barnett JR, Jeronimidis G (eds) wood quality and its biological basis, 53-86. Blackwell, United Kingdom.

Rydholm, S.A. (1965). Pulping processes, First Edition, s. 1269. Interscience Publishers.

Sjöström, E. (1981). The structure of wood, Chapter 1. Wood Chemistry Fundamentals and Applications. Academic Press Inc., San Diego, CA, USA, 1-20.

Tank, T. (1980). Fiber and Celluoce Technology. No: 2362/272, s.178. İstanbul: İ.Ü. Faculty of Foresty Publication.

Tappi T 203 om-93 (1992). Alpha-, beta- and gamma-cellulose of wood and pulp, TAPPI Test Methods, Tappi Press, Atlanta Georgia, I.

Tappi T-207 om-88 (19929). Water Solubility of Wood and Pulp, TAPPI Test Methods, Tappi Press, Atlanta Georgia, I. 
Tappi T-211 om-85 (1992). Ash in Wood and Pulp, TAPPI Test Methods, Tappi Press, Atlanta Georgia,I.

Tappi T-212 om-88 (1992). One percent Sodium Hydroxide Solubility of Wood and Pulp, TAPPI Test Methods, Tappi Press, Atlanta Georgia, I.

Tappi T 222 om-98 (1992). Lignin of wood and pulp, TAPPI Test Methods, Tappi Press, Atlanta Georgia, I.

Tappi T $232 \mathrm{~cm}-85$ (1992). Preparation of wood for fiber size determination, TAPPI Test Methods, Tappi Press, Atlanta Georgia, I.

Tappi 246 om-88 (1992). Moisture in pulp, paper and paperboard, TAPPI Test Methods, Tappi Press, Atlanta Georgia, I.

Tappi T-257 om-85 (1992). Sampling and Preparing wood for Analysis, TAPPI Test Methods, Tappi Press, Atlanta Georgia, I.

TS 4569 (1985). Determination of solute in wood-ether.

Wise, E.L. \& Karl, H.L. (1962). Cellulose and Hemicelluloses in Pulp and Paper Science and Technology, 1. Pulp. Earl. C.L. (Ed.). New York: McGraw Hill-Book Co. 